\title{
Migration and Fishing in Indonesian Coastal Villages
}

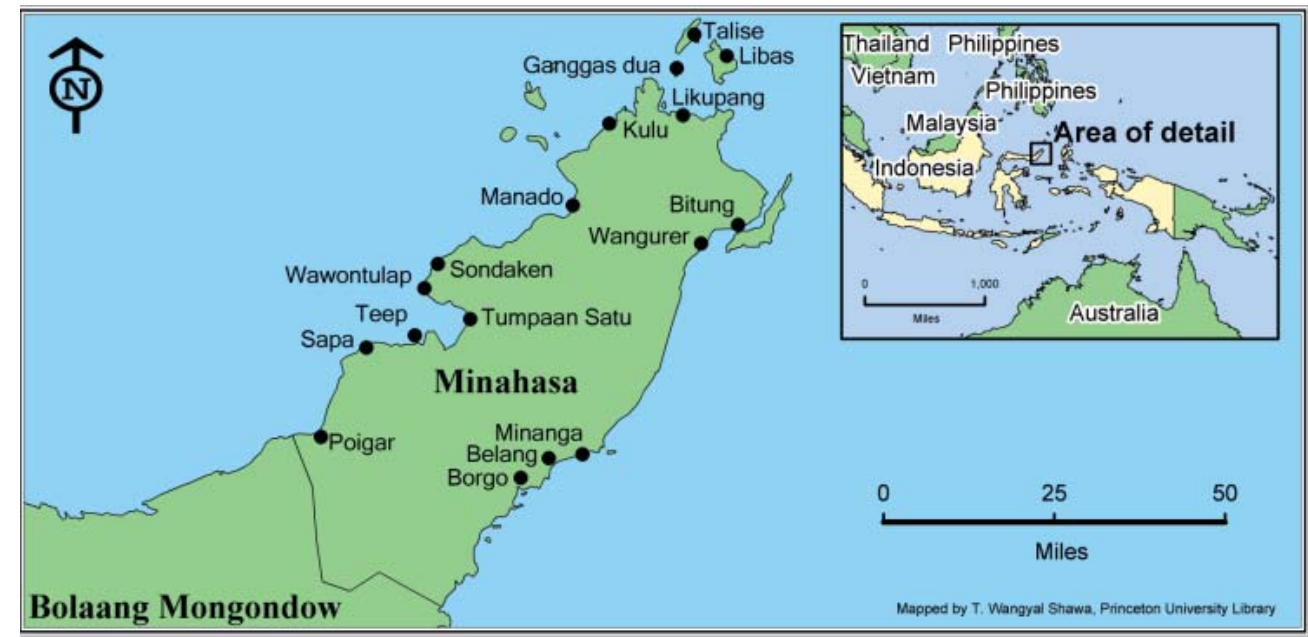

The coastal ecosystems in Southeast Asia are under increased pressure from local and global change. This paper examines human migration and the use of marine resources in coastal villages in the Minahasa district of North Sulawesi, Indonesia. Primary data were collected through interviews with village leaders, focus groups, and a sample survey of 600 fishing households. Migration is responsible for at least one quarter of the total growth during the past decade. All groups of fishermen report falling productivity of the nearshore fisheries. Econometric analysis is used to examine the weekly fish catch of the artisanal fishing sector. Migration status and socioeconomic variables seem to have no systematic effect, while fishing effort (labor, boat, and gear), the degree of specialization, and the remoteness of villages are found to be positively related to weekly fish catches.

\section{INTRODUCTION}

The world's marine resources have long been viewed as inexhaustible supplies of protein and other products for the human population. However, as the adverse effects of human activity on marine and coastal ecosystems have become better understood, views of the sustainability of resource use have changed. Globally, there are increasing concerns about the sustainability of marine and coastal fisheries, as marine catches have plateaued, and some fisheries have been closed entirely. This has led to calls for a better understanding of the biological and economic productivity of the ecosystems that humans inhabit, and for increased knowledge of ways to manage human effects on marine and coastal resources (1).

Coastal ecosystems are of great economic importance throughout Southeast Asia. The regions' fisheries supply the main source of animal protein in the region, and coral reefs supply $30 \%$ of the total fish catch (2). In Indonesia, the total annual fish catch in 1994 was 2.8 million tonnes, with $90 \%$ of this harvested by artisanal fishers. The region's coastal resources are under threat from coastal development, population growth, over-fishing, and climate related events, including widespread coral-bleaching (3). This paper reports on a study of human population changes and the use of coastal resources in several communities in North Sulawesi, Indonesia.
The area between Sulawesi and Irian Jaya has some of the highest levels of marine biodiversity in the world, and has been identified as a global priority area for marine conservation efforts (4). The province of North Sulawesi lies close to this fertile marine area and has a large population that depends on the coastal and marine resources for their economic well-being (5). One example of the importance of this region for marine biodiversity conservation was the discovery in 1998 of a population of coelacanth, a rare, primitive fish with a fossil record dating back 370 million years. Before this discovery, its habitat was thought limited to the Comoro Islands off the coast of Africa, 6000 miles away (6).

The study area is on the northern tip of North Sulawesi in the district of Minahasa, an area that has attracted many migrants in recent decades, among them many fishermen. Minahasa contains the Bunaken Marine National Park, one of the most popular marine parks in Southeast Asia. Nearly 10000 scuba divers travel from Indonesia, Southeast Asia, Europe, and North America to visit the park every year (7). The population of the province has been increasing at a rapid rate, particularly in areas near the capital of Manado. From 1980 to 2000, Manado's population more than doubled, from 228000 to $457000(8,9)$. Rapid increases in population in the area have been correlated with increases in destructive fishing practices, coastal erosion, and depletion of mangrove and forest trees (5).

\section{CONCEPTUAL MODEL}

A conceptual model is employed that draws on the production economics literature. The model was developed to explain the fishing behavior of small-scale Minahasa fishers. Such individuals fish from small canoes, sometimes with a motor or sail, extracting many different fish species with a variety of gear types. Rather than develop a utility theoretic supply function for a specific good, a simple model is used to shed light on the biophysical relationship between the inputs and outputs of the fishing activity at a somewhat aggregate level (10). The following relationship for the production of fish $(\mathrm{F})$ is postulated:

$\mathrm{F}=\mathrm{f}\left(\mathrm{L}_{\mathrm{i}}, \mathrm{K}_{\mathrm{i}}, \mathrm{R}_{\mathrm{i}}\right)$

where $\mathrm{L}_{\mathrm{i}}$ is the labor available from household $\mathrm{i}, \mathrm{K}_{\mathrm{i}}$ is the amount of capital owned by the household, and $R_{i}$ is the amount and quality of the available coastal resources available to each household (11). 
erage village population growth rate during the preceding decade was $2 \%$, although some villages grew at a rate 4 times faster, and some lost population. The ethnic diversity of the area is shown by the fact that some villages were 95\% Muslim, and some were almost entirely Christian. Some villages were dominated by fishing households; on average, fishing households made up $44 \%$ of the population. Table 1 also shows the average fish catch per unit of effort. On average, the artisanal fishermen in the sample caught $3.1 \mathrm{~kg}$ of reef fish or $3.4 \mathrm{~kg}$ of pelagic fish per hour of time spent fishing. There was great variation in this number across villages, indicating either variations in fishing skill or quality of nearby fish stock.

Migration status can be defined in a variety of ways. For example, whether a person was born in another village, another district, another province, or another country. For this study, we chose as our definition being born outside the Minahasa district (13). Many in our sample were born in other nearby villages. From the standpoint of managing coastal resources in the Minahasa area, accounting for fishermen moving among nearby villages within the region is less important than the new fishermen moving into the area from outside the region.

Three-fourths of our migrants originated from the SangirTalaud islands, located some 100 to $400 \mathrm{~km}$ to the northeast, between Sulawesi and the Philippines. To determine to what extent migration contributes to the overall growth rate of our fishing sub-population, we compared the number of migrants that arrived in the last 10 years with the number of children born during the same time-span. Of the household heads in the sample, 44 arrived in the Minahasa region in the past 10 years. Assuming that each household migrated with the average number of household members, this leads to a growth rate of $0.77 \%$ per year, which is due entirely to migration. During the last 10 years, the average number of children born per year to our sample of households was 59. Divided by the entire population of the households (2670), this leads to a growth rate of $2.21 \%$ per year that is due to solely to reproduction. Secondary sources put the net growth rate of our surveyed villages at $2.61 \%$. While these calculations embody many assumptions and imprecision, we make the tentative conclusion that approximately one quarter of the total gross population growth is due to in-migration rather

Table 1. Characteristics of the surveyed villages $(n=17)$.

\begin{tabular}{lrrr} 
& Average & Minimum & Maximum \\
\hline Population size & 2518 & 535 & 7115 \\
Population growth rate & $2 \%$ & $-5 \%$ & $8 \%$ \\
Muslim households & $38 \%$ & $0 \%$ & $95 \%$ \\
Fishing households & $44 \%$ & $10 \%$ & $95 \%$ \\
Number of fishing households & 242 & 32 & 566 \\
Catch per effort - Reef fish $^{1}$ & 3.1 & 0.6 & 10.6 \\
Catch per effort - Pelagic fish $^{1}$ & 3.4 & 0.7 & 13.1
\end{tabular}

${ }^{1}$ Catch per effort represents the average kilogram of fish per hour of time spent fishing by an artisanal fisherman with a three to six meter canoe with up to one extra crew member. This attempts to correct for different fishing types, i.e. capital investment, and hence is based on a sub-sample of our respondents.

Table 2. Distribution of respondents $(n=599)$ among village type and migration status.

\begin{tabular}{lcccc} 
Type of village & \multicolumn{3}{c}{ Migration status } & $\begin{array}{c}\text { Migrants as } \% \\
\text { of respondents }\end{array}$ \\
\cline { 2 - 4 } & Local & Migrant & Total & \\
\hline Remote & $19 \%$ & $2 \%$ & $21 \%$ & $\sim 10 \%$ \\
Rural & $41 \%$ & $8 \%$ & $49 \%$ & $\sim 16 \%$ \\
Urban & $15 \%$ & $15 \%$ & $30 \%$ & $\sim 50 \%$ \\
Total & $75 \%$ & $25 \%$ & $100 \%$ & $25 \%$ \\
& & & & \\
\hline
\end{tabular}

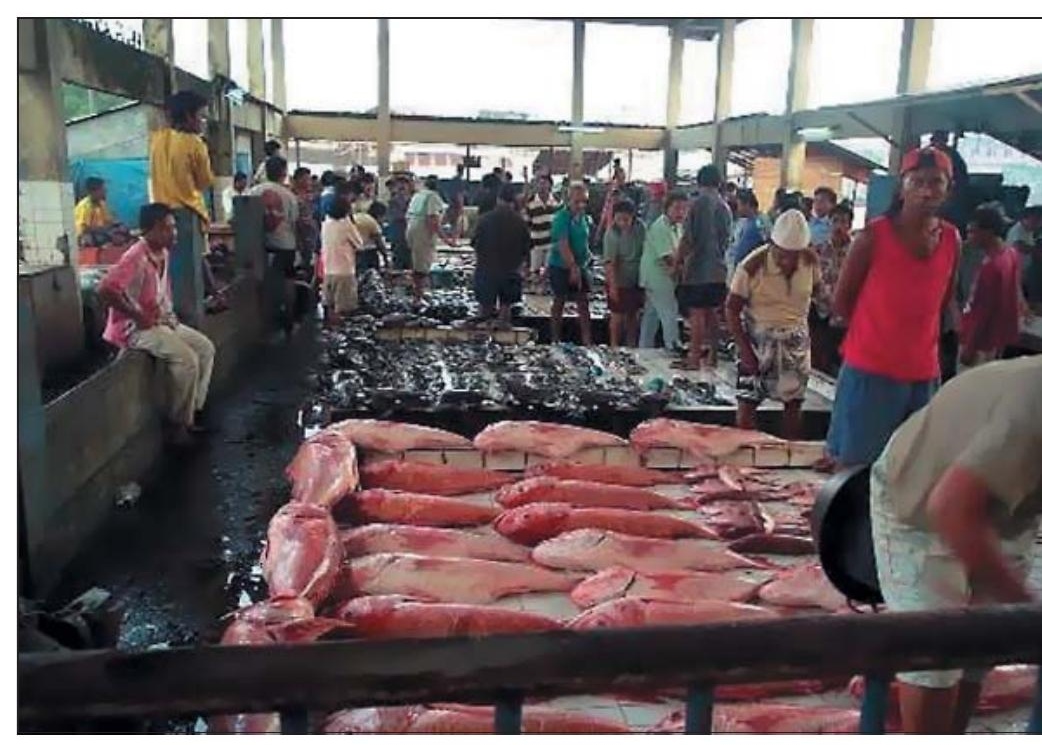

Fish Market in Manado, Indonesia. Photo: R. Kramer.

than reproduction. We have not accounted for the fact that much of the reproduction occurs in households whose members migrated into the area more than 10 years ago (approximately $18 \%$ of the surveyed households). When this element of reproductive growth is attributed to the effects of migration as well, the onequarter contribution to the overall gross population growth rate most likely represents a lower bound.

Table 2 reports the distribution of migration status by village type: remote, rural, or urban. "Remote" refers either to villages on the more distant islands (14), or villages with difficult or no road connection to the closest larger town. In either case, fishermen in remote villages face long transportation times, usually by boat, to market centers. "Urban" refers to villages within the municipal area of Bitung, which has a large fish market, fishprocessing factories, and a harbor for large fishing vessels. Villages between these extremes are labeled "rural." The remote villages contain $21 \%$ of our sample, and only $10 \%$ of their fishermen were migrants. The rural villages comprise roughly half our sample, of which $16 \%$ are migrants. The urban villages make up $30 \%$ of our sample, and are almost equally split between locals and migrants. Overall, one quarter of the fishermen interviewed were migrants.

When asked why they had moved to the village where they currently live, $58 \%$ of the migrants indicated it was to seek higher income (Table 3). The next most important reason for moving was to follow family. However, income motivations for moving were much stronger in the urban villages. As seen in Table 4, migration has been an important demographic force in the study villages for several decades. Slightly less than one third of the migrants arrived during the past decade. Since these data were generated by a cross-sectional survey (we do not observe attrition due to mortality and outmigration over time), we only can speculate that the rate of migration increased slightly over time.

There are further indicators that migration has been a significant force through the last half-century. In the sampled households, 31\% include marriage unions between a migrant and a local person. Migrants married a local Minahasan $63 \%$ of the time. One generation further, and $81 \%$ of all surveyed households have at least one grandparent (or parent) who is classified as a migrant, i.e. arrived from outside the Minahasa region.

The migration occurring from the Sangir-Talaud islands to Minahasa (three-fourths of the migrants in our sample) can be characterized further (15). The younger generation is leaving the islands, not because of resource pressure, but because they are 
drawn to the more-developed setting to seek job opportunities. Extensive family ties (networks), especially in the bigger towns, make the migration decision easier. While individuals originally are drawn to the bigger towns by employment opportunities in factories or on large fishing boats, when they stay, they often work as small-scale, independent fishermen in the more rural villages. Connections to place of their origin are maintained because remittances are often sent back. Also, when clove prices warrant, there exists a temporary return migration during harvest time to take advantage of the economic returns from this major crop on Sangir-Talaud. Overall, the intervening obstacles hindering migration (or in economic terms, the transaction costs) are low, which helps explain the large number of migrants. The preliminary evidence that the migration proceeds in stages is a further interesting feature.

Table 5 presents socioeconomic characteristics for the surveyed fishermen. The average fisherman in the sample was 39 years old, and had completed primary and some secondary schooling. On average, each fisherman had 2.6 children. Migrants tended to be slightly older and to have more children. Malaria was much more prevalent in the remote villages than in the rural and urban villages. In terms of wealth, $86 \%$ of the fishermen owned their own houses. Less than a third reported indoor plumbing, but plumbing was much more prevalent in the urban villages. Fishing was the primary economic activity of most of the subjects interviewed, with $71 \%$ reporting fishing as their primary occupation.

Information about fishing activity is reported in Table 6 . There are two distinct types of fishermen in the sample-artisanal and commercial. The artisanal fishermen are individuals with small,

\begin{tabular}{|c|c|c|c|c|}
\hline & $\begin{array}{c}\text { Remote } \\
n=13\end{array}$ & $\begin{array}{l}\text { Rural } \\
\mathrm{n}=46\end{array}$ & $\begin{array}{l}\text { Urban } \\
\mathrm{n}=91\end{array}$ & $\begin{array}{c}\text { Full sample } \\
n=150\end{array}$ \\
\hline $\begin{array}{l}\text { Higher income } \\
\text { Following wife } \\
\text { Following family } \\
\text { Due to commercial development } \\
\text { No response } \\
\text { Total }\end{array}$ & $\begin{array}{r}8 \% \\
23 \% \\
69 \% \\
0 \% \\
0 \% \\
100 \%\end{array}$ & $\begin{array}{r}50 \% \\
17 \% \\
26 \% \\
2 \% \\
4 \% \\
100 \%\end{array}$ & $\begin{array}{r}69 \% \\
4 \% \\
21 \% \\
4 \% \\
1 \% \\
100 \%\end{array}$ & $\begin{array}{r}58 \% \\
10 \% \\
27 \% \\
3 \% \\
2 \% \\
100 \%\end{array}$ \\
\hline
\end{tabular}

\begin{tabular}{lrcc|}
\multicolumn{5}{l}{ Table 4. Temporal pattern of migration $(\mathbf{n}=\mathbf{1 5 0})}$. \\
& & \# Migrants & $\%$ Migrants \\
\hline Arrived years ago & $0-10$ & 44 & $29 \%$ \\
& $11-20$ & 39 & $26 \%$ \\
& $21-30$ & 34 & $23 \%$ \\
& $31-40$ & 20 & $13 \%$ \\
& $41-50$ & 9 & $6 \%$ \\
Total & $>50$ & 4 & $3 \%$ \\
& & 150 & $100 \%$ \\
\hline
\end{tabular}

mostly wooden boats or canoes, 3 to 6 meters long, and rarely powered by a motor. They comprise the majority of our survey respondents. They fish by themselves, or occasionally with a family member, and their average catch ranges from a few kilograms to less than $100 \mathrm{~kg}$ fish per day. They usually fish closer to the shore and coral reefs (explaining their encounters with bomb and cyanide fishing and a lower incidence of encountering foreign fishermen noted later in the paper). These fishermen consume a portion of their catch and sell the rest directly to consumers, often through their wives, or to small traders from nearby villages. The second group is comprised either of individuals who own medium sized vessels, or those who work as crew members on larger, motorized fishing vessels that head farther off-shore. Their average daily catches are measured in hundreds of kilograms for owners, and in tonnes for crews. These fishermen usually sell their catch to traders who transport the fish great distances to large, often inland, markets. Since the large commercial fishing vessels require ports, the crew respondents are concentrated in the urban area of Bitung and to a lesser degree around the city of Belang. For purposes of analysis, we have used a threshold of $100 \mathrm{~kg}$ fish catch per trip. Those catching more than that are classified as commercial fishermen.

Overall, the average length of a fishing trip was $38.1 \mathrm{hrs}$, and the average time to fishing ground was $4.3 \mathrm{hrs}$ (see Table 6). Both of these numbers were considerably higher for crews engaged in commercial fishing, where fishing trips usually last multiple days. Artisanal fishermen, on the other hand, went on daily fishing trips lasting 9 to $10 \mathrm{hrs}$. About one quarter of the fishermen caught mostly reef fish (although commercial fishermen tend to catch very few reef fish, as they fish with boats in deep waters quite far from the reefs). The fishermen report that $62 \%$ of their catch is sold to fish traders. Not surprisingly, this number is lower for artisanal fishermen whose families consume the catch or sell directly to consumers. Of the artisanal fishermen $84 \%$ own their own boats. The catch in $\mathrm{kg}$ per hour of human labor varies greatly between artisanal and commercial fishermen, signifying the different capital investments (boat and gear) and fishing strategies.

Both artisanal and commercial fishermen reported noticeable declines in catches during the past 5 years (Table 7). Although questions that rely on recall may not be highly reliable, the fact that three-fourths of the respondents reported declining catches raises the possibility that fish stocks actually are in decline. A higher proportion of migrants than locals reported declines. Notably, the most frequently cited cause of fishing declines $(27 \%)$ was the presence of more fishermen in the area. In addition, commercial fishermen blamed foreign fishermen and artisanal fishermen blamed destructive fishing practices for the decline. Interestingly, those fishermen who feel the catch increased attribute this predominantly to having better fishing gear. Despite the declines in catches, $90 \%$ reported that if they had money available

Table 5. Socioeconomic characteristics of surveyed fishermen.

\begin{tabular}{|c|c|c|c|c|c|c|c|}
\hline & \multicolumn{2}{|c|}{ Remote } & \multicolumn{2}{|c|}{ Rural } & \multicolumn{2}{|c|}{ Urban } & \multirow{2}{*}{$\begin{array}{c}\text { Full } \\
\text { sample } \\
n=599\end{array}$} \\
\hline & $\begin{array}{c}\text { Local } \\
n=113\end{array}$ & $\begin{array}{c}\text { Migrant } \\
n=13\end{array}$ & $\begin{array}{c}\text { Local } \\
n=246\end{array}$ & $\begin{array}{c}\text { Migrant } \\
n=46\end{array}$ & $\begin{array}{l}\text { Local } \\
n=90\end{array}$ & $\begin{array}{c}\text { Migrant } \\
\mathrm{n}=91\end{array}$ & \\
\hline $\begin{array}{l}\text { Age (years) } \\
\text { Education level (mean) } \\
\text { Malaria incidence } \\
\text { Number of children (mean) } \\
\text { Household size (mean) } \\
\text { House ownership } \\
\text { Indoor plumbing } \\
\text { Ownership of farm land } \\
\text { Fishing as primary occupation }\end{array}$ & $\begin{array}{r}41.3 \\
2.4 \\
57 \% \\
2.7 \\
4.5 \\
93 \% \\
16 \% \\
65 \% \\
36 \%\end{array}$ & $\begin{array}{r}43.8 \\
2.4 \\
54 \% \\
3.1 \\
4.7 \\
100 \% \\
8 \% \\
73 \% \\
8 \%\end{array}$ & $\begin{array}{r}38.2 \\
2.5 \\
24 \% \\
2.7 \\
4.5 \\
88 \% \\
17 \% \\
26 \% \\
74 \%\end{array}$ & $\begin{array}{r}41.8 \\
2.3 \\
30 \% \\
2.7 \\
4.6 \\
83 \% \\
22 \% \\
34 \% \\
59 \%\end{array}$ & $\begin{array}{r}35.2 \\
2.6 \\
11 \% \\
2.1 \\
4.1 \\
76 \% \\
43 \% \\
2 \% \\
97 \%\end{array}$ & $\begin{array}{r}38.5 \\
2.6 \\
7 \% \\
2.4 \\
4.6 \\
80 \% \\
55 \% \\
2 \% \\
98 \%\end{array}$ & $\begin{array}{r}38.8 \\
2.5 \\
27 \% \\
2.6 \\
4.5 \\
86 \% \\
27 \% \\
31 \% \\
71 \%\end{array}$ \\
\hline
\end{tabular}


Table 6. Fishing activity and characteristics.

\begin{tabular}{|c|c|c|c|c|c|c|c|}
\hline & \multirow{2}{*}{\multicolumn{2}{|c|}{ Artisanal fishermen ${ }^{1}$}} & \multicolumn{4}{|c|}{ Commercial fishermen } & \multirow{3}{*}{$\begin{array}{l}\text { Full sample } \\
\qquad \mathrm{n}=599\end{array}$} \\
\hline & & & \multicolumn{2}{|c|}{ Boat owners } & \multicolumn{2}{|c|}{ Crew } & \\
\hline & $\begin{array}{c}\text { Local } \\
n=298\end{array}$ & $\begin{array}{c}\text { Migrant } \\
\mathrm{n}=56\end{array}$ & $\begin{array}{l}\text { Local } \\
n=40\end{array}$ & $\begin{array}{c}\text { Migrant } \\
\mathrm{n}=11\end{array}$ & $\begin{array}{c}\text { Local } \\
\mathrm{n}=111\end{array}$ & $\begin{array}{c}\text { Migrant } \\
n=83\end{array}$ & \\
\hline $\begin{array}{l}\text { Fishing as primary occupation } \\
\text { Length of trip (mean hours) } \\
\text { Time to fishing ground (mean hrs) } \\
\text { Catches mostly reef fish } \\
\text { Catch (mean kg per boat per trip) } \\
\text { Sells catch to trader } \\
\text { Boat ownership } \\
\text { - Motor or sail boat } \\
\text { - Length of boat (m) } \\
\text { - Size of entire crew } \\
\text { - Catch per labor effort } \\
\left(\mathrm{kg} \mathrm{hr}^{-1}\right)\end{array}$ & $\begin{array}{c}60 \% \\
9.5 \\
1.5 \\
40 \% \\
19 \\
45 \% \\
84 \% \\
21 \%{ }^{2} \\
4.71^{2} \\
1.62 \\
2.02\end{array}$ & $\begin{array}{c}50 \% \\
9.8 \\
1.3 \\
36 \% \\
21 \\
46 \% \\
84 \% \\
14 \%{ }^{2} \\
4.29^{2} \\
1.32 \\
2.12\end{array}$ & $\begin{array}{c}73 \% \\
11.9 \\
2.5 \\
13 \% \\
378 \\
73 \% \\
100 \% \\
70 \% \\
7.58 \\
5.7 \\
14.8\end{array}$ & $\begin{array}{c}82 \% \\
10.6 \\
1.6 \\
18 \% \\
509 \\
64 \% \\
100 \% \\
64 \% \\
7.59 \\
5.0 \\
12.7\end{array}$ & $\begin{array}{r}94 \% \\
75.2 \\
6.3 \\
1 \% \\
4,847 \\
91 \% \\
0 \% \\
-2 \\
-2 \\
-^{2} \\
-^{2}\end{array}$ & $\begin{array}{r}96 \% \\
126.1 \\
14.5 \\
0 \% \\
4,410 \\
88 \% \\
0 \% \\
-^{2} \\
-^{2} \\
-^{2} \\
-^{2}\end{array}$ & $\begin{array}{c}71 \% \\
38.1 \\
4.3 \\
24 \% \\
1,555 \\
62 \% \\
58 \% \\
18 \% \\
5.07 \\
2.1 \\
3.8\end{array}$ \\
\hline \multicolumn{8}{|c|}{$\begin{array}{l}{ }^{1} \text { Artisanal fishermen who do not own a boat usually borrow one from parents or share a boat with others. As a result, they do not } \\
\text { fall into the category of dependent labor and hence do not warrant separate listing. } \\
2 \text { Due to data limitations, we have only characteristics of the fishing boat for respondents who owned one. For artisanal fishermen, } \\
\text { these numbers are based on the sub-sample of boat owners }(84 \%) \text {. }\end{array}$} \\
\hline
\end{tabular}

to invest in business activities, they would invest it in fishing. Relatively few of the fishermen reported conflicts with other villages' fishermen, but more than $40 \%$ of the artisanal fishermen reported observing dynamite or cyanide fishing, nonsustainable fishing practices that destroy coral reefs and nontarget fish species. Some $9 \%$ of the artisanal and $56 \%$ of the commercial fishermen reported encounters with foreign fishermen. Encounters with foreign fishing fleets in the area were much more common for the commercial fishermen, because they fish in deeper waters where such fleets operate. Based on a 5-point, Likert-scale question, both groups of fishermen reported that they felt "bothered a lot" by foreign fishermen and destructive fishing practices.

Table 8 contains the results of estimating a fishing production function. The goal is to explain the effects of various inputs on fishing output. Ordinary least squares regression analysis is used with a dependent variable of weekly fish catch measured in kilograms. The sample of 297 for this analysis corresponds to the boat-owning, artisanal fisherman in our sample-those who catch less than $100 \mathrm{~kg}$ on an average fishing trip. The commercial fishermen are excluded due to their very different technologies and catches. There are 4 groups of independent variables in the model: labor (effort), physical capital, human capital, and village location. Overall, the model explains a significant amount of the variation in fish catch, and there is no evidence of multicollinearity. The adjusted $\mathrm{R}^{2}$ is 0.32 .

Not surprisingly, fishing effort has a strong positive effect on weekly catch. For every additional hour devoted to weekly fishing, about $1 \mathrm{~kg}$ of additional fish are caught. All of the physical capital variables have positive and significant effects on fish production. Other things being equal, those with longer boats, which correlates closely with having a sail, motor, or larger crew size, have greater weekly catches. While most gear groups are indistinguishable from the most common 'hook and line' gear type, the use of fly-fishing and coastal nets has a positive and significant effect on productivity. Most of the human capital variables
Table 8. Econometric analysis of weekly catch by artisanal fishers.

(Observations = 297; Adjusted R-squared $=0.317$ ).

\begin{tabular}{lccr} 
& Coefficient & t-ratio & Mean $^{1}$ \\
\hline Constant & -26.0 & -0.580 & \\
Time spent fishing (hrs week ${ }^{-1}$ ) & $1.0^{* * *}$ & 3.898 & 58.1 \\
Length of boat (m) & $11.3^{* *}$ & 2.353 & 4.7 \\
Fly-fish net gear dummy & $262.8^{* * *}$ & 8.076 & $7 \%$ \\
Coastal net gear dummy & $227.7^{* * *}$ & 5.180 & $4 \%$ \\
Age (years) & 0.4 & 0.526 & 40.3 \\
Education (secondary and beyond) & -8.3 & -0.439 & $28 \%$ \\
Migrant (born outside Minahasa) & -4.3 & -0.193 & $16 \%$ \\
Engages in agricultural activities & $-31.4^{*}$ & -1.755 & $58 \%$ \\
Lives in a "remote" village & $53.2^{* * *}$ & 2.804 & $34 \%$ \\
Note: * significant at the 0.10 level, ${ }^{* *}$ significant at 0.05 level, & \\
*** significant at 0.01 level. & &
\end{tabular}


are not significant in the model. The coefficients for the age, education, and migration variables are not significant. Given the similarities of local and migrant fishermen, the result for the migrant variable is not surprising. Those who engage in agricultural activity have significantly lower fish catches, perhaps due to less specialized skills. Those who farm catch $31 \mathrm{~kg}$ less fish per week on average, i.e. they have a lower catch even after correcting for their lower levels of effort. Finally, the dummy variable for remote villages is positive and strongly significant. This variable is picking up unique characteristics of the remote villages not captured by other variables in the model. We speculate that it can be interpreted as a proxy for resource quality, as there is probably less pressure on reefs and fish stocks in the more remote areas, both because of lower population density and the difficulty of getting fish to market.

\section{DISCUSSION}

There is considerable variation in fishing activities, migration, population growth, religion, resource status, and market access among our study villages. Yet it is clear that fishing remains the center of economic and cultural activity for many residents of coastal communities in the Minahasa district of North Sulawesi. There is some subjective indication of declining catches in the study area based on respondents' recollection of what fishing conditions were like 5 years ago. If catches have in fact declined, some of this may be due to natural forces such as changing weather patterns. Other possible sources are human related; there is substantial evidence of widespread use of destructive fishing practices. There is some indication that large markets may correlate with impaired local marine resources.

Human migration has affected fishing communities in the study area, with approximately one quarter of the fishermen born in another district. The Minahasa area attracts fishermen from other areas, largely due to job opportunities and strong fish markets. Once migration shifts get underway, other migrants follow their friends and family. Not surprising, the local and migrant fishermen are quite similar in many ways. This is in part because marriages between locals and migrants are quite common. The main resource effect of the migration is not through differential fishing behavior of migrants as compared to locals, but through overall population growth. We estimate that migration accounts for at least one quarter of the population growth in coastal villages during the past decade.

Migration is higher in the urban communities, where many of the migrants find jobs as crew members on large fishing vessels. The fishing conducted by these migrants is usually more industrial and targets offshore fish stocks. This migration appears driven largely by income opportunities. In contrast, the migration into rural and remote villages is driven more by family connections. The exploited fish stocks for these fishermen are found near-shore, including among the coral reefs. While the 2 groups of migrants target different fish resources, there is some overlap. Indonesian law forbids vessels over 5 gross tonnes from fishing within three miles of shore, so as to reserve the in-shore fisheries for small-scale fishermen. Yet this restriction rarely is enforced.

As the population in coastal villages of North Sulawesi continues to expand due to both fertility and migration, there will be growing pressure on the coastal marine resources. This suggests that the laissez faire approach to coastal marine resource management that has been typical in the past in Indonesia may need to be reexamined. More sustainable fishing could be encouraged by effective bans on destructive fishing methods such as blast fishing and live capture of reef fish with cyanide. Another policy approach to encourage sustainable fishing would be policy reforms that would allow limits on entry to protect local fishing grounds from fishermen from other areas (16).
1. National Research Council 1999. Sustaining Marine Fisheries. Committee on Ecosystem Management for Sustainable Marine Fisheries, Ocean Studies Board. National Academy Press, Washington, D.C.

2. Wilkinson, C.R. 1998. Status of Coral Reefs of the World. Townsville, Queensland, Australia. Published for the Global Coral Reef Monitoring Network by the Australian Institute of Marine Science, $184 \mathrm{pp}$

3. Hopley, D. and Suharsono. 2000. The Status of Coral Reefs in Eastern Indonesia. Australian Institute of Marine Science. (http://www.reefbase.org/Summaries/pdf/Indonesia1.pdf)

4. Olson, D.M. and Dinerstein, E. 1997. The Global 200: Conserving the World's Distinctive Ecoregions. Conservation Science Program, World Wildlife Fund-US, Washington, D.C

5. Pollnac, R.B., Rotinsulu, C. and Soemodinoto, A. 1997. Rapid Assessment of Coastal Management Issues on the Coast of Minahasa. USAID Coastal Resource Management Project, Report TE-97/01-E, Coastal Resources Center, University of Rhode Island.

6. Erdmann, M.V. 1999. An Account of the First Living Coelacanth Known to Scientists From Indonesian Waters. Environ. Biol. Fish. 54, 439-443.

7. Values of Preserving the Bunaken Coral Reef Ecosystem, North Sulawesi 1996. Natural Resources Management Project, U.S. Agency for International Development, Associates in Rural Development AID, Contract no. 497-0362, Report no. 65.

8. Biro Pusat Statistik. 1994. Proyeksi Penduduk Indonesia per Kabupaten/Kotamadya 1990-2000, Jakarta, Indonesia. (In Indonesian).

9. North Sulawesi Water Resources Management Plan 1998. Canadian International DeNorth Sulawesi Water Resources Managem
velopment Agency (CIDA), Vols. I \& II.

10. Optimally, each gear type would be considered a separate production technology, but given our data we need to abstract to a more general "artisanal fishing production function."

11. For other examples of household models of natural resource in a developing country context, see Bilsborrow, R.E. and Geores, M. 1992. Rural Population Dynamics and Agricultural Development: Issues and Consequences Observed in Latin America. Cornell University; and Pattanayak, S. and Kramer, R.A. 2001. Worth of Watersheds: A Producer Surplus Approach for Valuing Drought Mitigation in Eastern Indonesia. Environ. Develop. Econ. 6, 123-146.

12. Rea, L.M. and Parker, R.A. 1997. Designing and Conducting Survey Research: A Comprehensive Guide. Jossey-Bass, San Francisco, second edition.

13. There are four districts within the province of North Sulawesi. If one defines migrant as born in another village, then the percentage of migrants in our sample rises to $52 \%$.

4. Three of our seventeen villages are located on islands five to $16 \mathrm{~km}$ off the island of Sulawesi.

15. Information in this paragraph was provided by Susan Cassels, who conducted fieldwork on migration to North Sulawesi during the summer of 2001; Cassels, S. 2001. Migration and the Environment in North Sulawesi, Indonesia. Unpublished fieldnotes, Princeton University.

16. This research was funded in part by the John D. and Catherine T. MacArthur Foundation. The authors are indebted to Emi Yoda for research assistance, and they thank the editors and anonymous reviewers for helpful suggestions.

Randall Kramer is professor of resource and environmental economics in the Nicholas School of Environment and Earth Sciences, Duke University. His research focuses on ecosystem valuation, water resource economics, and the economics of biodiversity. He holds a PhD in agricultural economics from the University of California, Davis. His address: Box 90328, Duke University, Durham, N.C. 27708-0328, USA.

E-mail: kramer@duke.edu.

Sahat Simanjuntak is a senior lecturer in fisheries economics and development at Bogor Agricultural University, Bogor, Indonesia. He specializes in the economics of natural resource management in developing countries. He completed doctoral coursework in resource and environmental economics at the University of Rhode Island. His address is: Blok A III/3, Bogor Baru, Bogor, Indonesia.

E-mail: msjuntak@indo.net.id

Christopher Liese is a doctoral student at Duke University. He holds a masters in economics (Diplom VWL) from the University of Bonn, Germany. His dissertation research integrates methods from resource and agricultural economics with demographics to create an empirical model of a developing country's artisanal fishery. His address: Box 90328, Duke University, Durham, NC 27708-0328, USA. E-mail: C.Liese@duke.edu 